\title{
Intrathecal antibody synthesis in Lyme neuroborreliosis: use of recombinant p41 and a 14-kDa flagellin fragment in ELISA
}

\author{
R. KAISER, C. RASIAH*, G. GASSMANN* A. VOGT* and C. H. LÜCKING \\ Neurologische Klinik und Poliklinik der Universität Freiburg, Hansastrasse 9, W-7800 Freiburg and \\ - Institut für Medizinische Mikrobiologie und Hygiene der Universität Freiburg, \\ Hermann-Herder Strasse 11, W-7800 Freiburg, Germany
}

\begin{abstract}
Summary. The intrathecal synthesis of $\operatorname{IgM}$ and $\operatorname{IgG}$ antibodies to Borrelia burgdorferi sonicate, to recombinant flagellin $(41 \mathrm{kDa})$ and to a tryptic peptide of the flagellin $(14-\mathrm{kDa}$ fragment) was determined by ELISA in paired cerebrospinal fluid (CSF) and serum samples from 35 patients with Lyme neuroborreliosis (LNB) and in 10 patients with neurosyphilis. The antibody index $\left(A I=Q_{B b} / Q_{I g}\right)$ was calculated from the ratio between $C S F /$ serum quotients for specific antibodies $\left(\mathrm{Q}_{\mathrm{Bb}}\right)$ and total immunoglobulins $\left(\mathrm{Q}_{\mathrm{Ig}}\right)$. For the examination of IgG antibodies, the sonicate ELISA was performed with and without pre-absorption with Treponema phagedenis. Of 35 patients with LNB, 31 had intrathecal IgG response to $B$. burgdorferi demonstrated by sonicate ELISA ( 24 after absorption of cross-reactive antibodies), 29 had a response demonstrated by flagellin ELISA and 21 of 35 by 14-kDa ELISA. In patients with neurosyphilis the AI (IgG) was elevated in the sonicate ELISA in 7 of 10 samples (none of 10 after absorption of cross-reactive antibodies), in the flagellin ELISA in 5 of 10 samples and in the 14-kDa ELISA in none of 10 samples. Intrathecal synthesis of IgM antibodies to $B$. burgdorferi was demonstrated in patients with neuroborreliosis by sonicate ELISA in 20 of 35 samples, by flagellin ELISA in 16 of 35 samples and by 14-kDa ELISA in 9 of 35 samples. No intrathecal synthesis of $B$. burgdorferi-specific IgM could be detected by any assay in patients with neurosyphilis. The highest specificity and sensitivity was achieved with findings from IgG and IgM AI determinations in 14-kDa and sonicate ELISA (after preabsorption with $T$. phagedenis) providing positive results in $32(91.4 \%)$ of 35 patients.
\end{abstract}

\section{Introduction}

Since the identification of Borrelia burgdorferi as the organism responsible for Lyme disease, an increasing spectrum of neurological disorders has been associated with this infection. ${ }^{1-3}$ The most common forms of nervous system involvement are meningitis, cranial neuritis and painful radiculoneuritis, with myelopathy, encephalitis and psychiatric disorders reported less frequently. ${ }^{4-6}$ Diagnosis of Lyme disease is based chiefly on clinical evidence. The presence of erythema migrans is the best marker during the primary stage of infection, but these lesions may not always develop or they may manifest atypically. ${ }^{7}$ When clinical histories are incomplete, serological tests are often performed to identify the cause of infection.

In endemic areas, exposure to this spirochaete and consequently specific immunoreactivity - is widespread, making it difficult to determine if an individual patient's neurological problems are causally related to $B$. burgdorferi infection. ${ }^{8}$ False positive reactions can

Received 21 Jan. 1993; accepted 11 March 1993 also occur among individuals with syphilis and in areas where closely related Borrelia spp. co-exist with B. burgdorferi.${ }^{9,10}$ Attempts to increase the specificity of antibody tests have employed absorption of sera with Treponema phagedenis biotype Reiter or with Escherichia coli. ${ }^{10.11}$ This procedure reduces titres of cross-reactive antibodies, but may also decrease homologous titres. Another possible approach to improve the specificity and sensitivity of serological assays is the use of antigenic subunits of $B$. burgdorferi. ${ }^{12,13}$ However, the preparation of single antigen fractions is time consuming and requires large amount of bacteria. The expression of single $B$. burgdorferi proteins as recombinant molecules is an alternative method of preparing specific antigens. ${ }^{14,15}$

Immunoblotting has revealed that both IgM and IgG antibodies most commonly have specificity for the flagellin polypeptide $(41 \mathrm{kDa})$ of the spirochaete. ${ }^{16,17}$ Flagellae from different Borrelia spp. and other related eubacteria are antigenically related. ${ }^{15,18}$ However, cross-reactivity is largely reduced by the use of a tryptic peptide (14-kDa fragment) of the B. burgdorferi flagellin. ${ }^{19}$ 
Infections of the central nervous systems (CNS) commonly result in pathological changes in the cerebrospinal fluid (CSF). Besides non-specific reactions such as pleocytosis, damage to the blood-CSF barrier and the intrathecal synthesis of immunoglobulins of undetermined specificity (IgG-index, oligoclonal IgG bands), specific immune responses to the infectious agent may be established by CSF examination. ${ }^{20}$ Previous studies have indicated that the assessment of intrathecal synthesis of anti-B. burgdorferi antibody provides a useful marker of CNS infection. ${ }^{21,22}$

Therefore, the aim of our studies was to compare the sensitivity of different ELISA tests with $B$. burgdorferi sonicate, the recombinant $41-\mathrm{kDa}$ flagellin protein and the $14-\mathrm{kDa}$ fragment of the flagellin as antigens in determining a specific immune reaction of the CNS.

\section{Materials and methods}

\section{Subjects}

Thirty-five paired CSF and serum samples from 26 patients (age range 22-80 years) with early Lyme neuroborreliosis (ELN) and nine patients (age range 24-61 years) with late Lyme neuroborreliosis (LLN; duration of disease $>6$ months) were tested. ${ }^{1}$ Fifteen patients had VIIth cranial nerve palsy (nos. 1-14, 27), one had myelopathy (no. 15), 11 had painful meningoradiculitis (nos. 16-26), one of which also presented with papillitis (no. 26), seven patients suffered from spastic hemi- or paraparesis (nos. 28-34) and one patient from motor neuron disease (no. 35). A preceding erythema migrans had been reported in 13 patients; 14 individuals remembered a tick bite. All but two patients had lymphocytic pleocytosis in CSF-ELN: $23-600 \times 10^{6}$ cells/L (median cell count $235 \times 10^{6}$ cells $/ \mathrm{L}$ ); LLN: $10-120 \times 10^{6}$ cells/L (median, $45 \times 10^{6}$ cells $/ \mathrm{L}$ ), and a breakdown of the blood-CSF barrier $\left(\mathrm{Q}_{\mathrm{Alb}}=\right.$ albumin $\mathrm{CSF} /$ serum ratio $\left.>7.5 \times 10^{-3}\right)$-ELN: $10-58.4 \times 10^{-3}$ (median 12.0 $\times 10^{-3}$ ); LLN : 9.4-70.6 $\times 10^{-3}$ (median $31 \cdot 1 \times 10^{-3}$ ). Concentrations of albumin, IgG, IgM, and IgA in CSF and serum were determined by laser nephelometry (Beckmann Array System). Calculations by the Reiber-Formula ${ }^{23}$ revealed an intrathecal synthesis of IgG in 27 patients, of IgM in 27 and of IgA in 12 patients. Oligoclonal IgG bands ${ }^{24}$ were found in the CSF in 34 patients. Patients were treated with ceftriaxone ( $2 \mathrm{~g}$ daily) intravenously for 14 days. The first pre-treatment sample was taken 1 week- 4 years after the onset of neurological symptoms; CSF and sera were taken at the same time.

\section{Controls}

Paired CSF and serum samples from 10 patients with neurosyphilis without a history compatible with neuroborreliosis and from 30 patients with slipped lumbar disks served as controls.

\section{Routine Lyme borreliosis serology}

Screening for B. burgdorferi-specific antibodies in serum and CSF was done by an indirect immunofluorescence assay (IFA) according to standard techniques. ${ }^{25}$ The same $B$. burgdorferi sonicate was used for IFA as for ELISA. For IgG antibodies, specimens were tested with and without pre-absorption with $T$. phagedenis. Serum IgG titres $\geqslant 32$ and CSF IgG titres $\geqslant 2$ after absorption were considered to be positive results.

For the IgM-specific test, the samples were pretreated with anti-human IgG (RF-Absorbent, Behringwerke AG, Marburg, Germany). Serum IgM titres $\geqslant 48$ and CSF IgM titres $\geqslant 2$ were considered to be positive results.

\section{Preparation of antigen}

A single isolate of $B$. burgdorferi from ticks collected in the Freiburg area (Z-136) was used in this study. Spirochaetes were grown in modified Kelly's medium according to standard techniques ${ }^{26}$ and washed three times in phosphate-buffered saline (PBS, pH 7.4). The cells were resuspended in PBS and sonicated. For coating of ELISA plates, the $B$. burgdorferi sonicate was dissolved in $6 \mathrm{M}$ urea-PBS to a final protein concentration of $1.0 \mathrm{mg} / \mathrm{ml}$ and stored at $-20^{\circ} \mathrm{C}$. Further dilutions were done with PBS. For absorption studies, a sonicate of $T$. phagedenis was prepared in a similar manner and diluted to a final protein concentration of $1.0 \mathrm{mg} / \mathrm{ml}$.

The preparation of recombinant flagellin has been described previously. ${ }^{19}$ Spirochaetes and pellets of $E$. coli suspension cultures, containing the recombinant $41 \mathrm{kDa}$, were washed three times in PBS and sonicated. The recombinant flagellin was extracted with $8 \mathrm{M}$ urea. Purification was by ion-exchange chromatography with buffers containing $8 \mathrm{M}$ urea: anion-exchange chromatography with DEAE-Cellulose (Serva); cation-exchange-chromatography with SP-Sephadex C-50 (Pharmacia). The protein concentration was adjusted to $2 \mathrm{mg} / \mathrm{ml}$. Purified recombinant flagellin was used for the preparation of the $14-\mathrm{kDa}$ fragment. Flagellin-containing fractions were dialysed against distilled water; precipitated flagellin was resuspended in $0.1 \mathrm{M}$ Tris- $\mathrm{HCl}, \mathrm{pH} 7 \cdot 5$, and digested with trypsin (sequencing grade, Boehringer Mannheim) $1 \mu \mathrm{g} /$ $100 \mu \mathrm{g}$ of protein for $4 \mathrm{~h}$ at $37^{\circ} \mathrm{C}$. The resulting $14-\mathrm{kDa}$ fragment was purified by gel filtration (Superdex 75 HR 10/30; Pharmacia). From a 5-L culture of $E$. coli $3-6 \mathrm{mg}$ of $14-\mathrm{kDa}$ fragment was usually obtained.

\section{Reference serum}

For ELISA studies, antibody-positive sera from 25 patients were pooled and pre-diluted 200 -fold with dilution buffer for $\operatorname{IgM}$ (B. burgdorferi sonicate, flagellin, 14-kDa fragment), IgG (flagellin, $14-\mathrm{kDa}$ fragment) and 1000-fold for IgG antibodies ( $B$. burgdorferi sonicate). The pre-diluted serum pool was 
then further diluted with six serial two-fold dilution steps. Standard dilutions were chosen so that the corresponding absorbances were between 0.050 and $1.80 \mathrm{~A}$.

\section{Sample preparation}

Samples to be tested for IgG antibodies against $B$. burgdorferi sonicate, flagellin and the $14-\mathrm{kDa}$ fragment were diluted 200-, 1000- and 10000-fold (serum) and 10-, 50- and 500-fold (CSF). CSF and sera were investigated on the same microtitration plate with and without absorption with $T$. phagedenis. For absorption studies, $100 \mu \mathrm{l}$ of 100 -fold pre-diluted serum was incubated with $100 \mu \mathrm{l} T$. phagedenis $(1.0 \mathrm{mg} / \mathrm{ml})$ and $100 \mu \mathrm{l}$ of five-fold pre-diluted CSF was incubated with $100 \mu \mathrm{l}$ of $T$. phagedenis $(1.0 \mathrm{mg} / \mathrm{ml})$. After overnight incubation at $4^{\circ} \mathrm{C}$, samples were pelleted at $13000 \mathrm{~g}$ for $15 \mathrm{~min}$. The supernate was used for further dilution steps. Before IgM antibody assay, total IgG was immunoprecipitated according to Müller et al. ${ }^{27}$ Specimens to be tested for IgM antibodies were finally diluted 200and 2000-fold (serum) and 10- and 100-fold (CSF). Control samples were treated in the same way.

\section{ELISA procedure}

Determination of antigen-specific intrathecal antibody synthesis by ELISA was done according to Reiber et al. ${ }^{28}$ with slight modifications. Microtitration plates (Nunc Immunoplates) were coated overnight at $4^{\circ} \mathrm{C}$ with $50 \mu \mathrm{l}$ of $B$. burgdorferi sonicate $20 \mu \mathrm{g} / \mathrm{ml}$, purified recombinant flagellin $1 \mu \mathrm{g} / \mathrm{ml}$ or $14-\mathrm{kDa}$ fragment $1 \mu \mathrm{g} / \mathrm{ml}$ in PBS. The optimal concentration of proteins was determined in preliminary experiments by chessboard titrations of two-fold dilutions of antigen and high-titre sera. Non-specific protein binding was blocked with $100 \mu 1$ of dilution buffer (milk powder $3 \%$, bovine serum albumin [BSA] $1 \%$, Tween $200 \cdot 1 \%$ in PBS) for $1 \mathrm{~h}$. The wells were then washed with Tween $0 \cdot 1 \%$ in PBS, and $50 \mu$ of the appropriate dilution of specimen, control and standard serum was added to the wells and incubated for $2 \mathrm{~h}$ at room temperature. After washing, $50 \mu \mathrm{l}$ of peroxidase-conjugated goat anti-human IgM (1 in 4000 ) or goat anti-human IgG antibodies (1 in 10000; Dianova, Hamburg, Germany) was added. After $1.5 \mathrm{~h}$ at room temperature the plates were washed and $50 \mu \mathrm{l}$ of $o$-phenylenediamine (OPD) in citrate buffer ( $\mathrm{pH} 5$ ) with $\mathrm{H}_{2} \mathrm{O}_{2} 0.04 \%$ was added to each well. The enzymic reaction was stopped after $20 \mathrm{~min}$ by the addition of $30 \mu \mathrm{l}$ of $2 \cdot 5 \mathrm{~N} \mathrm{H}_{2} \mathrm{SO}_{4}$. The optical densities (ODs) at $492 \mathrm{~nm}$ was measured with a Titertek Multiscan reader (FlowLab, Meckenheim, Germany). ODs that were 3 standard deviations above the mean OD of 30 negative controls were defined as a positive antibody response to $B$. burgdorferi. Samples were tested in duplicate and the mean value was calculated. Negative controls were included on every plate.
This ELISA technique allowed the quantification of relative concentrations of specific antibodies in CSF and serum instead of antibody titres; ODs of the reference sample were related to arbitrary concentration units. The greatest measurable standard concentration (OD 1.8) was defined as 1000 arbitrary concentration units. The standard values (reference sample) were evaluated in a $\log / \log$ diagram (OD/ relative concentrations). Final antibody concentrations in CSF and serum were calculated by multiplication of relative concentration units with the dilution factor.

\section{Evaluation of specific antibody synthesis in the CNS}

Specific antibody synthesis in the CNS was calculated by the antibody index $\left(\mathrm{AI}_{\mathrm{Bb}}\right)$ which is defined as the ratio between the $\mathrm{CSF}$ /serum quotient for specific antibodies $\left(\mathrm{Q}_{\mathrm{AB}}\right)$ and the quotient of total IgG concentration in CSF and serum $\left(\mathrm{Q}_{\mathrm{IgG}}\right)$.

$$
A I=\frac{\text { antibody concentration-CSF }}{\text { antibody concentration-serum }}: \frac{I g G-C S F}{I g G-\text { serum }}
$$

Any quotient $\geqslant 1.5$ was considered to be indicative of an intrathecal antibody response to $B$. burgdorferi antigens. Calculations for intrathecal synthesis of specific IgM antibodies were performed in a similar fashion. ${ }^{28}$

\section{SDS-PAGE and immunoblotting}

SDS-PAGE and subsequent blotting was done according to previously described methods ${ }^{29}$ with the following modifications: $B$. burgdorferi lysates and flagellin were electrophoresed in a discontinuous SDSgel, with an acrylamide $4 \%$ stacking gel and an acrylamide $12 \%$ resolving gel. The molecular masses of the proteins were determined by co-electrophoresis of known standards (BioRad). Gels were loaded with $100 \mu \mathrm{g}$ of antigen (B. burgdorferi) and $16 \mu \mathrm{g}$ of purified flagellin/8-cm width. Electrophoresis was performed at a constant voltage of $200 \mathrm{~V}$ for $1 \mathrm{~h}$ in a BioRad Minicell. Proteins were transferred electrophoretically from the gel to a nitrocellulose (NC) membrane in phosphate buffer ( $\mathrm{pH} \mathrm{9.0)}$ ) at $1 \mathrm{~A}$ for $1 \mathrm{~h}$. NC membranes were cut into 5-mm strips and used for testing. After blocking for $1 \mathrm{~h}$ at room temperature with dilution buffer (milk powder $3 \%$, BSA $1 \%$, Tween 20 $0.1 \%$ in PBS), the strips were incubated with $0.5 \mathrm{ml}$ of CSF and serum, each diluted to an IgG or IgM concentration of $10 \mathrm{mg} / \mathrm{L}$. Testing for IgM antibodies was performed after pre-absorption of $\mathrm{IgG}$ antibodies according to Müller. ${ }^{27}$ After $2 \mathrm{~h}$, the strips were washed three times with Tween $200 \cdot 1 \%$-PBS and incubated for $1 \mathrm{~h}$ at room temperature with peroxidase-labelled goat anti-human IgM ( 1 in 500) or goat anti-human IgG (1 in 1000). The NC strips were developed by the addition of a freshly prepared solution of 4-chloronaphthol (Sigma) $3 \mathrm{mg} / \mathrm{ml}$ and $\mathrm{H}_{2} \mathrm{O}_{2} 0.015 \%$ in PBS for $10 \mathrm{~min}$. The reaction was 
Table I. Calculation of the IgG AI (normal $<1.5$ ) with different $B$. burgdorferi antigen preparations

\begin{tabular}{|c|c|c|c|c|c|}
\hline $\begin{array}{l}\text { Patient } \\
\text { no. }\end{array}$ & $\begin{array}{c}\text { Course } \\
\text { of } \\
\text { disease }\end{array}$ & B. burgdorferi & $\begin{array}{c}\text { B. burgdorferi } \\
\text { plus absorption }\end{array}$ & $\begin{array}{l}\text { Flagellin } \\
41 \mathrm{kDa}\end{array}$ & $\begin{array}{c}\text { Fragment } \\
14 \mathrm{kDa}\end{array}$ \\
\hline 1 & Acute & $18 \cdot 0$ & $3 \cdot 4$ & $<1.5$ & $<1.5$ \\
\hline 2 & Acute & $7 \cdot 4$ & 1.5 & $2 \cdot 1$ & 1.8 \\
\hline 3 & Acute & 43.0 & $<1.5$ & $9 \cdot 2$ & $3 \cdot 4$ \\
\hline 4 & Acute & $33 \cdot 8$ & 6.8 & $12 \cdot 5$ & $7 \cdot 2$ \\
\hline 5 & Acute & $11 \cdot 2$ & $2 \cdot 2$ & $9 \cdot 1$ & $2 \cdot 5$ \\
\hline 6 & Acute & $3 \cdot 2$ & $<1.5$ & $3 \cdot 2$ & $2 \cdot 3$ \\
\hline 7 & Acute & $2 \cdot 3$ & 1.7 & $7 \cdot 7$ & 5.8 \\
\hline 8 & Acute & $47 \cdot 5$ & 62.5 & $11 \cdot 9$ & $19 \cdot 0$ \\
\hline 9 & Acute & 1.7 & $26 \cdot 6$ & $3 \cdot 6$ & $2 \cdot 5$ \\
\hline 10 & Acute & $1 \cdot 5$ & $<1.5$ & $2 \cdot 1$ & $1 \cdot 8$ \\
\hline 11 & Acute & $<1.5$ & $<1.5$ & $<1.5$ & $<1.5$ \\
\hline 12 & Acute & $10 \cdot 0$ & $11 \cdot 7$ & $3 \cdot 4$ & 8.9 \\
\hline 13 & Acute & $2 \cdot 1$ & $<1.5$ & $1 \cdot 5$ & $<1.5$ \\
\hline 14 & Acute & $52 \cdot 0$ & 133.0 & $10 \cdot 0$ & $<1.5$ \\
\hline 15 & Acute & $<1.5$ & $<1.5$ & $3 \cdot 1$ & $4 \cdot 3$ \\
\hline 16 & Acute & $2 \cdot 8$ & 1.9 & $5 \cdot 3$ & $3 \cdot 1$ \\
\hline 17 & Acute & $3 \cdot 7$ & $4 \cdot 1$ & $<1.5$ & $<1.5$ \\
\hline 18 & Acute & $12 \cdot 2$ & $20 \cdot 0$ & $12 \cdot 0$ & $2 \cdot 1$ \\
\hline 19 & Acute & $6 \cdot 1$ & $8 \cdot 5$ & $6 \cdot 2$ & $<1.5$ \\
\hline 20 & Acute & 27.6 & $<1.5$ & $3 \cdot 4$ & $<1.5$ \\
\hline 21 & Acute & $<1.5$ & $<1.5$ & $<1.5$ & $<1.5$ \\
\hline 22 & Acute & $<1.5$ & $<1.5$ & $<1.5$ & $<1.5$ \\
\hline 23 & Acute & $11 \cdot 8$ & 19.4 & $<1.5$ & $<1.5$ \\
\hline 24 & Acute & 1.8 & $2 \cdot 7$ & $4 \cdot 7$ & $<1.5$ \\
\hline 25 & Acute & $3 \cdot 4$ & 26.8 & $19 \cdot 4$ & $6 \cdot 1$ \\
\hline 26 & Acute & $12 \cdot 1$ & $24 \cdot 0$ & $14 \cdot 7$ & $8 \cdot 0$ \\
\hline 27 & Chronic & $3 \cdot 3$ & $<1.5$ & 1.5 & $<1.5$ \\
\hline 28 & Chronic & $2 \cdot 4$ & $2 \cdot 6$ & $2 \cdot 6$ & $<1.5$ \\
\hline 29 & Chronic & $7 \cdot 1$ & 30.0 & 15.7 & 13.0 \\
\hline 30 & Chronic & $2 \cdot 0$ & $6 \cdot 1$ & $5 \cdot 6$ & $8 \cdot 2$ \\
\hline 31 & Chronic & $17 \cdot 5$ & $<1.5$ & $11 \cdot 2$ & $6 \cdot 1$ \\
\hline 32 & Chronic & 3.5 & 8.6 & 3.9 & $8 \cdot 4$ \\
\hline 33 & Chronic & $7 \cdot 7$ & $2 \cdot 5$ & $3 \cdot 4$ & $<1.5$ \\
\hline 34 & Chronic & $3 \cdot 4$ & 1.5 & $5 \cdot 3$ & $9 \cdot 1$ \\
\hline 35 & Chronic & $8 \cdot 2$ & $43 \cdot 6$ & 18.7 & 11.9 \\
\hline
\end{tabular}

stopped by washing the strips with distilled water. The monoclonal antibody H9724 was used to identify the 41-kDa protein. Intrathecal synthesis of antibodies to the $B$. burgdorferi proteins was assessed either from the isolated presence or more intense staining of antibody bands in CSF.

\section{Results}

\section{Routine Lyme borreliosis serology (IFA)}

Screening for $B$. burgdorferi-specific antibodies was performed by an IFA. After pre-absorption with $T$. phagedenis, $30(85.7 \%)$ of 35 neuroborreliosis patients were IgG antibody positive in serum and $29(82.8 \%)$ of 35 in CSF. Seven of 10 patients with neurosyphilis also had elevated IgG titres in serum and four of 10 in $\mathrm{CSF}$; all samples gave negative results after preabsorption with $T$. phagedenis.

Elevated IgM titres (after absorption of IgG antibodies) were demonstrated in serum in $16(45.7 \%)$ patients and in CSF in $17(48.5 \%)$ patients. Controls were negative both with serum and CSF. With regard to elevated titres of either IgM or IgG antibodies, or both, in serum, $32(91.4 \%)$ of 35 samples gave positive results. The same number of patients had elevated titres of either IgG or IgM antibodies, or both, in the CSF.

\section{Intrathecal synthesis of IgM and IgG antibodies to $B$. burgdorferi antigens}

Table I shows the AI calculated from IgG antibody concentrations in ELISA. With B. burgdorferi sonicate the AI was elevated in $31(88.5 \%)$ of 35 samples (ELN: 22; LLN: 9). After pre-absorption of cross-reactive antibodies $24(68.5 \%)$ of 35 samples (ELN : 17; LLN: 7) still gave positive results. Intrathecal synthesis of IgG antibodies to the flagellin was demonstrated in 29 $(82.8 \%)$ of 35 samples (ELN: 20; LLN: 9); serum antibodies to this protein were detected in all 35 samples. In 20 of 29 samples (ELN: 14; LLN: 6) with an intrathecal IgG response to the flagellin protein these antibodies were specific for the 14-kDa fragment. Serum IgG antibodies to the 14-kDa fragment were detected in 30 of 35 samples (ELN: 22; LLN: 8). Fig. 1 shows the frequency of elevated IgG antibody indices in sonicate ELISA, with and without pre-absorption of cross-reactive antibodies, in flagellin and $14-\mathrm{kDa}$ fragment ELISA. Combined analysis with the 14-kDa 


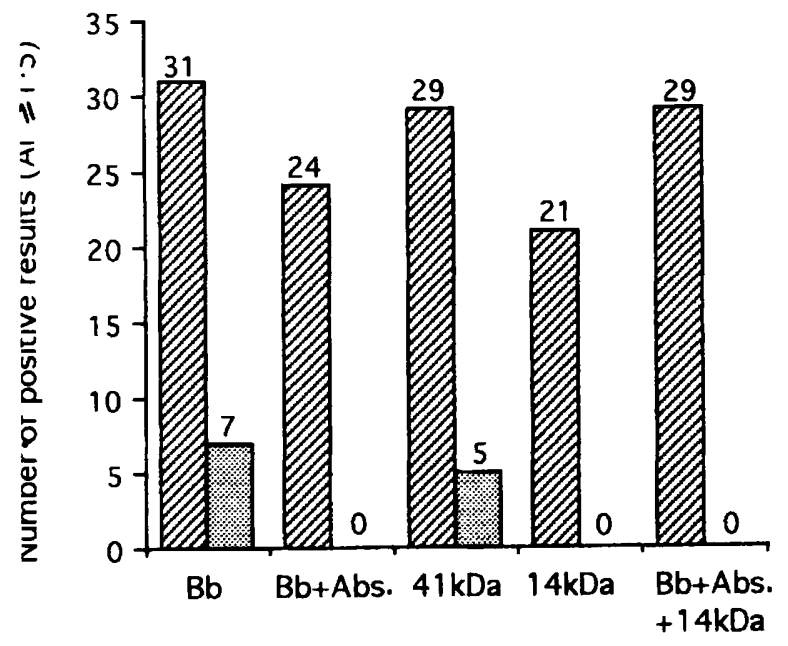

Fig. 1. Intrathecal synthesis of IgG antibodies to $B$. burgdorferi in 35 patients with neuroborreliosis ( $\square$ ) and 10 with neurosyphilis (圆). The sonicate ELISA was performed, with and without preabsorption of cross-reactive antibodies (Abs) with B. burgdorferi sonicate $(\mathrm{Bb})$, flagellin $(41 \mathrm{kDa})$ and $14-\mathrm{kDa}$ ELISA. The fifth column represents a combined analysis of results from $14-\mathrm{kDa}$ ELISA and from sonicate ELISA after pre-absorption of crossreactive antibodies.

ELISA and the sonicate ELISA, after pre-absorption of cross-reactive antibodies, was as sensitive as the flagellin ELISA alone ( 29 of 35 ) but more specific, as some patients with neurosyphilis gave positive results only in the latter assay.

After pre-absorption of cross-reactive antibodies in sonicate ELISA the AI value dropped below the upper reference limit (1.5) in seven samples (nos. $3,6,10,13,20,27$ and 31). The flagellin ELISA gave elevated AIs in all these samples; four of them (nos.
$3,6,10$ and 31) also gave positive results in the $14-\mathrm{kDa}$ ELISA. One sample (no. 15) gave negative results in the sonicate ELISA before and after pre-absorption with $T$. phagedenis but positive results in the flagellin and 14-kDa ELISA. In three samples (nos. 1, 17 and 23) with negative findings in the flagellin ELISA but positive results in sonicate ELISA, Western blotting demonstrated an intrathecal IgG response to $\mathrm{p} 47, \mathrm{p} 60$ and $\mathrm{p} 67$ of $B$. burgdorferi.

Among the controls, seven of 10 patients with neurosyphilis had elevated AIs (7.1-72.2) in sonicate ELISA, in all of whom results became negative after pre-absorption with $T$. phagedenis. Five of 10 neurosyphilis patients were also positive in the flagellin ELISA (AI: 2.1-68.8); all samples (CSF and sera) gave negative results in the 14-kDa ELISA.

Western blotting of CSF and sera was performed to examine the specificity of intrathecally produced antibodies for individual $B$. burgdorferi proteins. Fig. 2 demonstrates the findings in two samples with a low (no. 27) and a high (no. 31) intrathecal IgG reaction to the flagellin protein. In patients with no intrathecal immune response to the flagellin protein, but elevated AIs in sonicate ELISA, locally produced IgG antibodies were reactive with $\mathrm{p} 45(\mathrm{n}=6), \mathrm{p} 31$ (5), p60 (4) and with $\mathrm{p} 67$ and $\mathrm{p} 80$ (3) of $B$. burgdorferi.

Intrathecal synthesis of $B$. burgdorferi-specific IgM antibodies was demonstrated by sonicate ELISA in 20 $(57.1 \%)$ of 35 samples (ELN: 16 ; LLN: 4), by flagellin ELISA in $16(45.7 \%)$ of 35 samples (ELN: 13; LLN: 3 ), and by the 14-kDa ELISA in $9(25.7 \%)$ of 35 samples of patients with ELN. The detailed data are listed in table II. In 12 samples, AI values in the

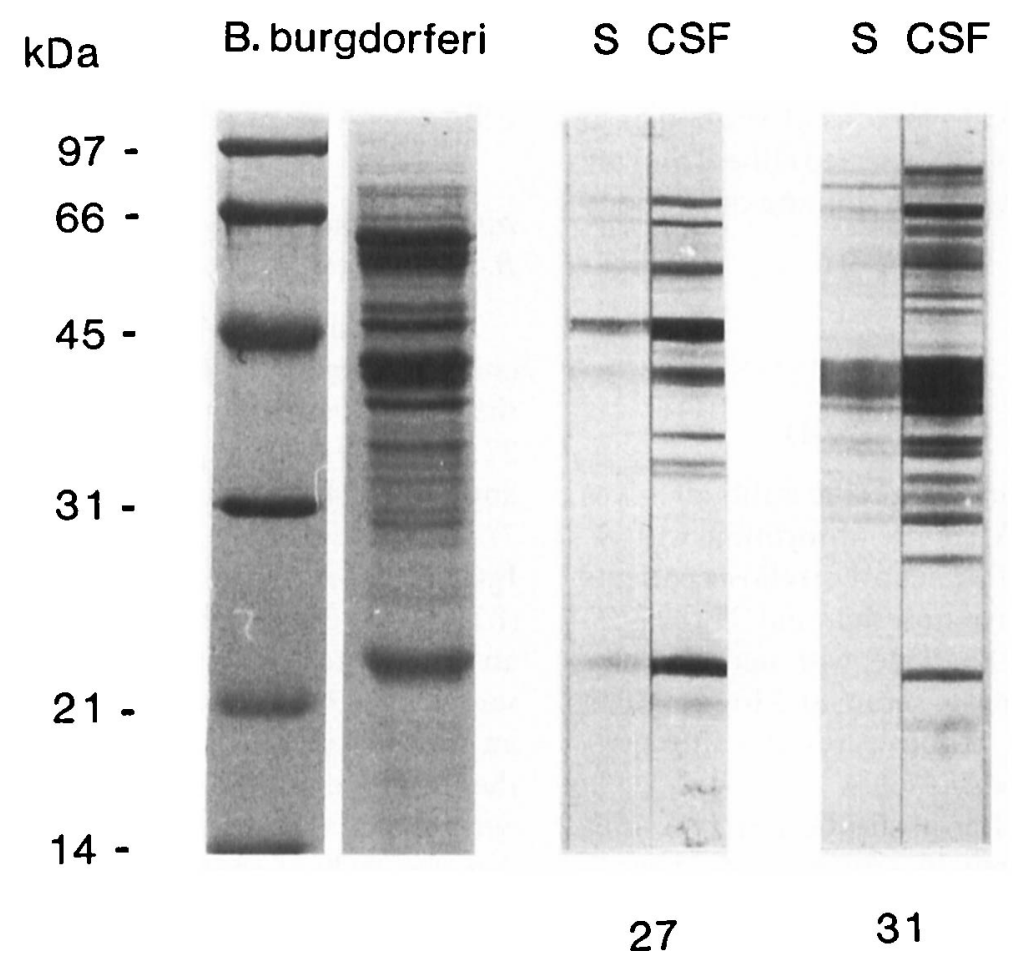

Fig. 2. Western blotting of CSF and sera (S) to B. burgdorferi sonicate. Demonstration of a low (patient no. 27) and high (patient no. 31) intrathecal IgG response to the flagellin protein (p41). 
Table Il. Calculation of the IgM AI (normal < 1.5) with different $B$. burgdorferi antigen preparations

\begin{tabular}{|c|c|c|c|c|}
\hline $\begin{array}{c}\text { Patient } \\
\text { no. }\end{array}$ & $\begin{array}{c}\text { Course } \\
\text { of } \\
\text { disease }\end{array}$ & B. burgdorferi & $\begin{array}{l}\text { Flagellin } \\
41 \mathrm{kDa}\end{array}$ & $\begin{array}{c}\text { Fragment } \\
14 \mathrm{kDa}\end{array}$ \\
\hline 1 & Acute & $4 \cdot 2$ & $<1.5$ & $<1.5$ \\
\hline 2 & Acute & $<1.5$ & 3.6 & $1 \cdot 5$ \\
\hline 3 & Acute & $2 \cdot 5$ & $25 \cdot 0$ & $5 \cdot 3$ \\
\hline 4 & Acute & $4 \cdot 1$ & $10 \cdot 5$ & $14 \cdot 1$ \\
\hline 5 & Acute & $4 \cdot 0$ & $9 \cdot 3$ & $10 \cdot 8$ \\
\hline 6 & Acute & $<1.5$ & $25 \cdot 0$ & $1 \cdot 5$ \\
\hline 7 & Acute & $2 \cdot 2$ & $3 \cdot 2$ & 7.9 \\
\hline 8 & Acute & $27 \cdot 0$ & $<1.5$ & $<1.5$ \\
\hline 9 & Acute & $78 \cdot 0$ & $5 \cdot 3$ & $4 \cdot 2$ \\
\hline 10 & Acute & $<1.5$ & 1.6 & 1.7 \\
\hline 11 & Acute & 1.6 & $2 \cdot 1$ & $2 \cdot 3$ \\
\hline 12 & Acute & 4.6 & $<1.5$ & $<1.5$ \\
\hline 13 & Acute & $<1.5$ & $<1.5$ & $<1.5$ \\
\hline 14 & Acute & $11 \cdot 3$ & 13.4 & $<1.5$ \\
\hline 15 & Acute & $1 \cdot 7$ & $1 \cdot 5$ & $<1.5$ \\
\hline 16 & Acute & $<1.5$ & $2 \cdot 3$ & $<1.5$ \\
\hline 17 & Acute & $<1.5$ & $<1.5$ & $<1.5$ \\
\hline 18 & Acute & 1.5 & $<1.5$ & $<1.5$ \\
\hline 19 & Acute & $<1.5$ & $<1.5$ & $<1.5$ \\
\hline 20 & Acute & $<1.5$ & $<1.5$ & $<1.5$ \\
\hline 21 & Acute & $1 \cdot 6$ & $<1.5$ & $<1.5$ \\
\hline 22 & Acute & $2 \cdot 0$ & $<1.5$ & $<1.5$ \\
\hline 23 & Acute & $23 \cdot 7$ & $<1 \cdot 5$ & $<1.5$ \\
\hline 24 & Acute & $<1.5$ & $<1.5$ & $<1.5$ \\
\hline 25 & Acute & 1.7 & 1.5 & $<1 \cdot 5$ \\
\hline 26 & Acute & $<1.5$ & $<1.5$ & $<1.5$ \\
\hline 27 & Chronic & $<1.5$ & $<1.5$ & $<1.5$ \\
\hline 28 & Chronic & 1.8 & $24 \cdot 8$ & $<1.5$ \\
\hline 29 & Chronic & 1.5 & $3 \cdot 0$ & $<1.5$ \\
\hline 30 & Chronic & $<1.5$ & $<1.5$ & $<1.5$ \\
\hline 31 & Chronic & $<1.5$ & $<1.5$ & $<1.5$ \\
\hline 32 & Chronic & 1.5 & 1.6 & $<1.5$ \\
\hline 33 & Chronic & $2 \cdot 1$ & $<1.5$ & $<1.5$ \\
\hline 34 & Chronic & $<1.5$ & $<1.5$ & $<1.5$ \\
\hline 35 & Chronic & $<1.5$ & $<1.5$ & $<1.5$ \\
\hline
\end{tabular}

flagellin ELISA were higher than in the sonicate ELISA. In four (nos. 2, 6, 10 and 16) of these 12 samples, the intrathecal synthesis of $B$. burgdorferispecific IgM antibodies could be established only from findings in flagellin ELISA (AI: 1.6-25.0). Three of these samples (nos. 2, 6 and 10) also had elevated AIs in the 14-kDa ELISA. In the eight patients with negative results in flagellin ELISA, but positive findings in sonicate ELISA, intrathecally produced IgM antibodies were reactive mainly with $B$. burgdorferi proteins $\mathrm{p} 47, \mathrm{p} 22$ and $\mathrm{p} 67$. With respect to the intrathecal synthesis of B. burgdorferi-specific IgM antibodies, controls gave negative results in the sonicate, flagellin and 14-kDa ELISA.

As regards the intrathecal immune response to $B$. burgdorferi, all 35 patients had either IgM or IgG antibodies, or both, in the $B$. burgdorferi sonicate ELISA (without pre-absorption with $T$. phagedenis); $29(82.8 \%)$ of 35 still gave positive results after preabsorption of cross-reactive IgG antibodies; 30 $(85.7 \%)$ of 35 gave positive results in the flagellin ELISA, and $22(62.8 \%)$ gave positive results in the $14-\mathrm{kDa}$ ELISA. In the sonicate ELISA after preabsorption of samples with $T$. phagedenis and in the 14kDa ELISA, 91.4\% (32 of 35) of neuroborreliosis patients, but none of the neurosyphilis patients, provided evidence of an intrathecal immune response to $B$. burgdorferi (neither IgG nor IgM).

\section{Discussion}

Although clinical criteria are most important in the diagnosis of Lyme neuroborreliosis, definitive proof of this disease relies on serological confirmation. An important diagnostic tool is the measurement of specific antibodies in the CSF. However, elevated antibodies in the CSF might result from diffusion through the altered blood-CSF barrier or from intrathecal synthesis. In the latter case, locally produced antibodies are assumed to originate from plasma cells that have been activated by antigen in the CNS. Therefore, the demonstration of an intrathecal synthesis of antigen-specific antibodies represents a good indicator for a CNS infection. However, in serodiagnosis of bacterial infections several aspects that reduce the diagnostic significance of antibody reactions have to be considered. These include the difficulties in standardisation of antigen preparations from bacterial organisms, the different expression of certain antigens by various strains and the relative amounts of cross-reactive antibodies leading to false positive results. The production of recombinant antigenic proteins might help to avoid these problems. Although several studies have indicated an improved diagnostic sensitivity and specificity in early Lyme disease with purified $B$. burgdorferi flagellin as antigen in ELISA, ${ }^{30.31}$ others could not confirm this observation. ${ }^{32}$

Our study demonstrated the significance of crossreactive antibodies and the possible diagnostic value of a 14-kDa fragment from the flagellin in the laboratory diagnosis of neuroborreliosis. In a sonicate ELISA, $88.5 \%$ of neuroborreliosis patients had evidence of an intrathecal IgG response to $B$. burgdorferi. The sensitivity of this assay was greatly reduced (to $68.5 \%$ ), if samples were re-tested after absorption of crossreactive antibodies. However, specificity was improved, as seven patients with neurosyphilis, who had positive results in sonicate ELISA had negative results after absorption of samples with $T$. phagedenis. Compared to the sonicate ELISA with pre-absorption of cross-reactive antibodies, the sensitivity in detecting an intrathecal immune response to $B$. burgdorferi was improved with recombinant flagellin as antigen $(82 \cdot 8 \%)$. The specificity of this antigen preparation was only slightly better than that of the $B$. burgdorfer $i$ sonicate, as five patients with neurosyphilis also had elevated AIs in flagellin ELISA. A significant improvement of the specificity was achieved with the 14$\mathrm{kDa}$ fragment of the flagellin, instead of the complete protein. None of the controls had antibodies to this polypeptide. Sensitivity in demonstrating an intrathecal IgG response to $B$. burgdorferi in patients with neuroborreliosis was greatly reduced in the $14-\mathrm{kDa}$ 
ELISA (to $60 \%$ ) and was lower than for the sonicate ELISA with pre-absorption of cross-reactive antibodies. However, analysis of results from both assays showed that at least $29(82 \%)$ of 35 patients gave positive results in either 14-kDa ELISA or sonicate ELISA with pre-absorption of cross-reactive IgG antibodies, or both.

Hansen and colleagues tested 56 patients with Lyme neuroborreliosis and reported an increase in the diagnostic sensitivity in detecting serum antibodies to $B$. burgdorferi by use of purified $B$. burgdorferi flagellum instead of $B$. burgdorferi sonic extracts. ${ }^{30}$ However, the flagellum-based ELISA did not improve the diagnostic sensitivity of measurement of antibodies to $B$. burgdorferi in CSF. Although these authors demonstrated a marked decline in OD values in sera from patients with primary syphilis, the use of flagellum ELISA did not actually reduce the number of false positive results with sera. This observation is in agreement with our findings in patients with neurosyphilis and intrathecal synthesis of $\mathrm{IgG}$ antibodies to $B$. burgdorferi and flagellin - although in our study patients with neurosyphilis gave negative results in the 14-kDa ELISA.

Intrathecal synthesis of B. burgdorferi-specific IgM antibodies was demonstrated less frequently. Preabsorption was done only for IgG antibodies (rheumatoid factor), and removal of cross-reacting anti- bodies was not found to be necessary for IgM. Replacement of the $B$. burgdorferi sonicate in ELISA by flagellin or the $14-\mathrm{kDa}$ fragment was associated with a lower sensitivity of $57 \cdot 1,45 \cdot 7$ and $25 \cdot 7 \%$, respectively. Combination of results from sonicate ELISA and flagellin or 14-kDa ELISA improved the sensitivity to $68.5 \%$ and $62.8 \%$, respectively, in detecting an intrathecal synthesis of IgM antibodies to B. burgdorferi.

The loss in sensitivity accompanying measures to increase specificity is a common observation in diagnostic assays. The combination of different assays offers a means to achieve a high specificity along with a high sensitivity.

In our study a high sensitivity $(91.4 \%)$ was achieved if samples were examined for both $\operatorname{IgG}$ and $\operatorname{IgM}$ antibodies in 14-kDa ELISA as well as in sonicate ELISA, after pre-absorption of samples with $T$. phagedenis. Sensitivity was decreased to $82.8 \%$ if testing in the 14-kDa ELISA was omitted. Therefore, the 14-kDa ELISA can be recommended for samples from patients with suspected neuroborreliosis that give uncertain results in routine examination.

This study was supported by grant no. 01K19001/0 from the German Federal Ministry for Research and Technology (Bundesministerium für Forschung und Technologie). We thank Gisela Fleig for her expert and skillful technical assistance and S. Batsford for help in editing the manuscript.

\section{References}

1. Reik L (ed). Lyme Disease and the nervous system. New York, Stuttgart, Thieme Med. Publisher. 1991: 52-110.

2. Steere AC. Medical progress: Lyme disease. $N$ Engl J Med 1989; 321 : 586-596.

3. Finkel MF. Lyme disease and its neurologic complications. Arch Neurol 1988; 45: 99-104.

4. Pfister HW, Einhäupl KM, Wilske B, Preac-Mursic V. Bannwarth's syndrome and the enlarged neurological spectrum of arthropod-borne borreliosis. Zentralbl Bakteriol Mikrobiol Hyg $[A]$ 1987; 263: 343-347.

5. Ackermann R, Hörestrup P, Schmidt R. Tick-borne meningopolyneuritis (Garin-Bujadoux, Bannwarth). Yale $J$ Biol Med 1984; 57: 485-490.

6. Ackermann R, Rehse-Küpper B, Gollmer E, Schmidt R. Chronic neurologic manifestations of erythema migrans borreliosis. Ann NY Acad Sci 1988; 539: 16-23.

7. Weber K, Neubert U. Clinical features of early erythema migrans disease and related disorders. Zentralbl Bakteriol Mikrobiol Hyg [A] 1986; 263: 209-228.

8. Mautner VF, Gittermann M, Freitag V, Schneider E. Zur Epidemiologie der Borrelia burgdorferi-Infektion. Abhängigkeit der Durchseuchungsrate von den serologischen Bestimmungsverfahren. Nervenarzt 1990; 61: 94-97.

9. Magnarelli LA, Anderson JF, Johnson RC. Cross-reactivity in serological tests for Lyme disease and other spirochetal infections. J Infect Dis 1987; 156: 183-188.

10. Craft JE, Grodzicki RL, Steere AC. Antibody response in Lyme disease: evaluation of diagnostic tests $J$ Infect Dis 1984; 149: 789-795.

11. Fawcett PT, O'Brien AE, Doughty RA. An adsorption procedure to increase the specificity of enzyme-linked immunosorbent assays for Lyme disease without decreasing sensitivity. Arthritis Rheum 1989; 32: 1041-1044.
12. Magnarelli LA, Anderson JF, Barbour AG. Enzyme-linked immunosorbent assays for Lyme disease: Reactivity of subunits of Borrelia burgdorferi. J Infect Dis 1989; 159: 43-49.

13. Grodzicki RL, Steere AC. Comparison of immunoblotting and indirect enzyme-linked immunosorbent assay using different antigen preparations for diagnosing early Lyme disease. J Infect Dis 1988; 157: 790-797.

14. Howe TR, Mayer LW, Barbour AG. A single recombinant plasmid expressing two major outer surface proteins of the Lyme disease spirochete. Science 1985; 227: 645-646.

15. Gassmann GS, Jacobs E, Deutzmann R, Göbel UB. Analysis of the Borrelia burgdorferi GeHo fla gene and antigenic characterization of its gene product. $J$ Bacteriol $1991 ; 173$ : 1452-1459.

16. Craft JE, Fischer DK, Shimamoto GT, Steere AC. Antigens of Borrelia burgdorferi recognized during Lyme disease. Appearance of a new immunoglobulin $\mathbf{M}$ response and expansion of the immunoglobulin $\mathrm{G}$ response late in the illness. J Clin Invest 1986; 78: 934-939.

17. Wilske B, Schierz G, Preac-Mursic V et al. Intrathecal production of specific antibodies against Borrelia burgdorferi in patients with lymphocytic meningoradiculitis (Bannwarth's syndrome). J Infect Dis 1986; 153: 304-314.

18. Barbour AF, Hayes SF, Heiland RA, Schrumpf ME, Tessier SL. A Borrelia-specific monoclonal antibody binds to a flagellar epitope. Infect Immun 1986; 52 : 549-554.

19. Rasiah C, Schiltz E, Reichert J, Vogt A. Purification and characterization of a tryptic peptide of Borrelia burgdorferi flagellin, which reduces cross-reactivity in immunoblots and ELISA. J Gen Microbiol 1992; 138: 147-154.

20. Forsberg P, Kam-Hansen S, Frydén A. Production of specific antibodies by cerebrospinal fluid lymphocytes in patients with herpes zoster, mumps meningitis and herpes simplex virus encephalitis. Scand J Immunol 1986; 24: 261-271

21. Stiernstedt GT, Granström M, Hederstedt B, Sköldenberg B. Diagnosis of spirochetal meningitis by enzyme-linked 
immunosorbent assay and indirect immunofluorescence assay in serum and cerebrospinal fluid. J Clin Microbiol $1985 ; 21: 819-825$.

22. Steere AC, Berardi VP, Weeks KE, Logigian EL, Ackermann R. Evaluation of the intrathecal antibody response to Borrelia burgdorferi as a diagnostic test for Lyme neuroborreliosis. J Infect Dis 1990; 161: 1203-1209.

23. Reiber HO. Aktuelle Methoden der Liquoranalytik. Lab Med 1988; 12: 101-109.

24. Kaiser R. Affinity Immunoblotting: rapid and sensitive detection of oligoclonal IgG, $\operatorname{IgA}$ and IgM in unconcentrated CSF by agarose isoelectric focusing. I Neurol Sci 1991; 101 : $216-225$.

25. Russel H, Sampson JS, Schmid GP, Wilkinson AW, Plikaytis B. Enzyme-linked immunosorbent assay and indirect immunofluorescence assay for Lyme disease. $J$ Infect Dis $1984 ; 149: 465-470$.

26. Barbour AG. Isolation and cultivation of Lyme disease spirochetes. Yale J Biol Med 1984; 57 : 521-525.

27. Müller F, Moskophidis M, Borkhardt HL. Detection of immunoglobulin $\mathbf{M}$ antibodies to Treponema pallidum in a modified enzyme-linked immunosorbent assay. Eur J Clin Microbiol 1987; 6: 35-39.

28. Reiber HO, Lange P. Quantification of virus-specific antibodies in cerebrospinal fluid and serum: sensitive and specific detection of antibody synthesis in brain. Clin Chem 1991; 37: 1153-1160.

29. Towbin H, Staehlelin T, Gordon J. Electrophoretic transfer of proteins from polyacrylamide gels to nitrocellulose sheets: procedures and some applications. Proc Natl Acad Sci USA 1979; 76: 4350-4354.

30. Hansen K, Hindersson P, Strandberg Pedersen N. Measurement of antibodies to the Borrelia burgdorferi flagellum improves serodiagnosis in Lyme disease. J Clin Microbiol 1988; 26 : 338-346.

31. Grodzicki RL, Steere AC. Comparison of immunoblotting and indirect enzyme-linked immunosorbent assay using different antigen preparations for diagnosing early Lyme disease. J Infect Dis 1988; 157: 790-797.

32. Coleman JL, Benach JL. Isolation of antigenic components from the Lyme disease spirochete: their role in early diagnosis. J Infect Dis 1987; 155: 756-765. 